\title{
Clinical Trial Core Documentation
}

National Cancer Institute

\section{Source}

National Cancer Institute. Clinical Trial Core Documentation. NCI Thesaurus. Code

C115646.

Records pertaining to the core trial of a clinical trial. 